\title{
The Link Between a New Language Teaching Technique and Learners' Traditional Beliefs
}

\author{
Thomas A. Williams \\ University of Szeged (Hungary)
}

Received: 15 September 2011 / Accepted: 3 May 2012

ISNN: $1697-7467$

\begin{abstract}
This paper explores the relationship between individuals' expectations of language learning and their readiness to accept a particular language teaching paradigm. The participants are students in an upper-intermediate speaking class at a southern Hungarian university. The study reviews the typical kinds of language learning experience in the Hungarian educational context, which in turn form learners' expectations, and discusses the implications that learners' expectations may have for their own language learning and - should they become teachers themselves - for their own language teaching. The paper describes the three research perspectives that inform it: the task-based language teaching (TBLT) paradigm; classroom-based research; and learner beliefs. The two phases of the research had 56 participants engaged in two speaking tasks and, of these, 28 involved in one-on-one, semi-structured interviews. The respondents' answers are discussed in terms of their experience of learning form and their teachers' classroom management as well as their impressions of the speaking tasks they had just performed in the classroom. The paper then discusses the possibilities for methodological change in a context marked by traditional teaching and learning techniques.
\end{abstract}

Keywords: task-based language teaching, classroom-based research, learner beliefs.

La relación entre una nueva técnica de enseñanza de lenguas y las creencias tradicionales del alumnado

RESUMEN: Este artículo explora la relación entre las expectativas de los alumnos al aprender idiomas y su predisposición para aceptar un cierto paradigma de enseñanza de la lengua. Los participantes son alumnos de una clase de conversación de nivel intermedio alto en una universidad del sur de Hungría. El estudio revisa los tipos de experiencias de aprendizaje de idiomas típicas del contexto educativo húngaro, que, a su vez afecta a las expectativas del alumnado, y analiza las consecuencias que las expectativas de los alumnos pudieran tener en su propio aprendizaje de lenguas y - en el caso de que lleguen a ser profesores - en como abordarían la enseñanza de idiomas. Se describen las tres perspectivas de investigación que conforman el artículo: el paradigma de enseñanza de lenguas por tareas, la investigación en el aula y las creencias del alumnado. Las dos fases de la investigación tuvieron cincuenta y seis participantes implicados en dos actividades de conversación, y de estos, veintiocho realizaron entrevistas individuales semiestructuradas. Las respuestas obtenidas se analizan teniendo en cuenta tanto su experiencia de aprendizaje como la gestión del la clase realizada por sus profesores así como también sus impresiones sobre las actividades de conversación que se habían llevado a cabo. Finalmente el artículo plantea distintas posibilidades para el cambio metodológico en un contexto marcado por una enseñanza y unas técnicas de aprendizaje tradicionales.

Palabras clave: aprendizaje de lenguas por tareas, investigación en el aula, creencias del alumnado. 


\section{INTRODUCTION}

Steeped in a schooling tradition described by White (1988) as classical humanist, the educational landscape of Hungary shares many of the features of that of its neighbours on what Blagojević (2004) calls the "semiperiphery" of Europe - a term for the point in the social, political, and economic development of a country or region, so called because it is thought to be situated halfway between the developing periphery and the developed core. Within this context, and specifically in Hungary, EFL teaching is marked by "a close reliance on textbooks and a strong concern for accuracy, drilling, and rote learning" (Pintér, 2007:135).

Against this backdrop, the present study uses one-on-one interviews to explore the individual EFL (and other FL) learning histories of upper-intermediate Hungarian EFL learners enrolled in an English BA course at the University of Szeged in Szeged, Hungary. It analyses their reflections on their own experience of participating in task-based lessons and performing speaking tasks. The study aims to ascertain how years of experience with the teaching/learning paradigm noted above impact upon a learner's view of such tasks in language education. The paper discusses the implications of these learners' beliefs for their own language learning.

\section{The CONTEXT}

In this section, I will describe the context of the study and more specifically the class within which the classroom phase of the study took place. I will then discuss the educational expectations of the learners involved. Finally, I will cover the link between learner expectations and the cognitions learners develop as future teachers.

\subsection{The Communication Skills class}

The specific context in which the learners in this study find themselves is Communication Skills, an upper-intermediate English for Academic Purposes (EAP) speaking class at the University of Szeged in southern Hungary. One 90-minute session is organised every week during one term and forms part of students' language practice in Year 1 of a threeyear Bologna-compliant undergraduate course. The aim of the speaking class is to provide learners with an opportunity to develop both the interactional and transactional speaking skills that are required for their studies - and beyond - and, more immediately, to prepare them for an advanced speaking exam at the end of their first year.

The vast majority of these learners have acquired English in primary and secondary schools in Hungary, an experience which naturally informs what Tonkyn has aptly called their "script", i.e. their educational expectations, for FL learning (Alan Tonkyn, personal communication). The rest of the learners come from other regions of Europe and thus bring with them their own FL learning scripts, which tend to be quite distinct from the Hungarians'. (These learners' language learning histories are not included in this study).

Almost all of the University of Szeged students are specialized in English or American Studies while the rest are taking a minor in one of these fields and studying another main 
subject in the arts and sciences (for example maths, history, or German language and literature). Similar to other Hungarian universities, it is a long-standing tradition that the medium of instruction in all English and American Studies classes is English. This teaching practice generally obtains at Hungarian universities (for instance at the German, French, and Italian languages and literatures programmes) and in a number of other countries in the region, such as Serbia and Romania (Erzsébet Barát, personal communication). Although the methodology of teaching in Szeged's English and American Studies classes ranges from tutor lecturing to more student-activating methods (including discussions and student presentations), using English as the medium of instruction clearly presupposes that students possess a strong command of academic English.

\subsection{Hungarian learners' script}

What is the script that Hungarian learners have developed during their language learning careers? In a number of studies carried out in Hungarian primary schools (Bors, Lugossy, and Nikolov 2001; Nikolov 1999, 2000, 2003; Nikolov and Nagy 2003), Marianne Nikolov and her colleagues found that actual teaching practice varies widely. In one study involving learners in Years 6 and 8, it was found that, while practice does include Communicative Language Teaching that centres on meaning-making, role play, real-world situations, and authentic materials with learners being actively involved and using language to reach relevant goals, teacher-fronted class interaction with the teacher asking closed questions and learners answering individually was far more common. Furthermore, in both German and English language classes, the traditions of grammar-translation and drills remained strong: reading aloud, translating, and performing grammar exercises were among the most frequent student activities, while watching videos, engaging in discussions, role plays, and language games were among the least frequent activities.

Nor did the learners find any of this to be motivating. Retrospective interviews carried out by Nikolov and Nagy (2003) revealed that the most common procedures were found to be the least motivating and vice versa. These findings echoed observations at schools with disadvantaged children (Nikolov 1999).

In another study in Hungary involving 30 EFL teachers' classes in Years 1-5, Nikolov (2008) used classroom observation and teacher interviews to place participants' teaching practice into three broad categories based on the degree to which they reflected generally accepted principles of primary language teaching: good, acceptable, and to be avoided.

Eight out of the 30 teachers were considered to use good language teaching practices. They varied the types of activities they asked their learners to perform, engaging them in activities that were clear and interesting, that they could perform at a good pace, and that was in line with their attention span and interests. Most of the learners working in groups were active and appeared to enjoy their work and to understand what their teachers expected of them. Their teachers taught the class in English for the most part, regularly evaluated their learners' work, had clearly established a rapport with the children, and aided them in their development by providing sufficient examples, providing them with opportunities to practice, and paying attention to the learners' reactions and work.

Twelve of the 30 teachers were thought to use acceptable, mixed practices. They sometimes used activities that were motivating, challenging, and suitable for their learners' age and language ability. At other times, they focused on language form, grammar practice, 
translation, and mechanical drills. They often had discipline problems and only some of the children fully participated in activities. They used English half or less of the class time. In fact, they often used Hungarian in situations when the target language would also have been appropriate, for example in giving directions, explaining activities, disciplining, and evaluating.

Finally, 10 out of the 30 teachers used classroom practices that were deemed to be less than optimal. They often used L1 in class, even exclusively in many cases, while class size was very small (2-3). They organised activities that their learners appeared to find boring, and their classroom interaction was entirely teacher-fronted, consisting of translation exercises, explicit instruction of grammar rules, and memorization and repetition of context-reduced vocabulary, while unsuccessful disciplining was common.

In terms of motivation, barring monotonous activities, the children in all the classes were enthusiastic, active, interested, and motivated. Of the teachers, 16 were relatively motivated and enthusiastic, while 14 were disheartened, depressed, impatient, dissatisfied, and, in some cases, antagonistic with the children. As became clear in the interviews, they would prefer to be teaching in the upper primary years or in secondary school.

Secondary school pupils appear to be exposed to similar teacher-fronted, grammarand translation-oriented paradigms. Having observed the language learning script of their first-year TEFL students at the Eötvös Loránd University in Budapest, Rádai and Shanklin (1996:29) noted that their students "seem to believe that the explicit learning of rules can improve their language competence." In training their students to become effective learners, they also found that the learners were only familiar with the traditional method of keeping vocabulary notebooks with a discrete English-language item on the left and its Hungarian equivalent on the right. Other approaches, such as associative tasks and context-related word cards with alternate forms were unfamiliar. In my own experience, first-year students at the University of Szeged are often uncertain and therefore hesitant about a vocabulary building task that invites them to use a new, thematically unified set of vocabulary to describe their own meaning. Rádai and Shanklin (1996:29-30) also found that, far from being part of a process of actively developing a lexical repertoire tied to their individual needs, students felt it to be the tutor's responsibility to select new vocabulary items for them to learn - clearly a reflex from years of teacher-led, teacher-fronted language learning.

Similarly, Rádai and Shanklin (1996:31) found that Year 1 learners prefer the tutor to instruct them explicitly on language rules they are to commit to memory and see a tutor who does so as a competent authority. They are disinclined to analyse and compare language rules themselves. However, if a tutor provides different solutions "based on context, changing use, language variety, or -God forbid- uncertainty, the tutor is viewed as less competent or wishy-washy" (ibid.). One tutor noted a typical first-year student response to his efforts to raise language awareness: "I feel learners wish to be presented with a lot of rules - that's what school trained them for. They want to see language black and white. I was also taught English like that. Now it's hard to be an analyst" (Pohl 1994, cited in Rádai and Shanklin 1996:31).

\subsection{Teachers in the making}

English language teacher training in Hungary has traditionally relied heavily on courses in literature and theoretical linguistics with methodology courses "regarded as add-ons" 
followed by a "brief spell of actual teaching practice" (Medgyes 1996:1). While a fair command of English is assumed, the basic philosophy is that English language teachers should be experts in the humanities and develop teaching skills as they go (ibid.).

While important teacher training reforms were implemented in Hungary in the early 1990s (see Medgyes and Malderez (1996) for a review of a programme at the Eötvös Loránd University in Budapest), ELT training, with minimal tuition in second language teaching principles, remains fairly traditional. Methodology modules are centred on presenting a string of methods and approaches in primarily practical terms and in a chronological order that culminates in the perceived orthodoxy of the day, which still represents the state of the field around the time the reforms were first implemented by the Hungarian government and when funding and other resources from the British Council and other Western organisations were injected into the system. Indeed, these courses offer little connection to any principles that may have informed these methods or approaches or to any empirical evidence that may bear out their effectiveness in the classroom.

The methodology exam at the end of the training elicits declarative rather than procedural knowledge (Ildikó Pálos, personal communication). Examinees are not asked to assess or apply particular teaching principles, compare or contrast different principles, or synthesize or analyse the knowledge they have acquired. While a nationally mandated 10-page classroom research paper represents an attempt to have teacher trainees forge a link between teaching theory and practice, the rest of the training tends to neglect these links. Indeed, in writing about his own ELT practitioner/trainer colleagues at the Eötvös Loránd University, Pohl (1996:47) observes that an "applied science model" (Wallace, 1991) in Hungarian university education has left most of them suspicious of the role of theory in teacher education - and thus fosters their determination to steer clear of the perceived dangers of what White (1988) calls theory-driven practice.

Nor is a sense of lifelong learning or a critical approach to learning ingrained in the students. Medgyes and Malderez (1996:113) report that students in their context "are unused to taking responsibility for their own learning and, as successful products of the system, they often have difficulty challenging the models of teaching and learning that worked for them."

While teacher training may well be ineffectual, the methodological example that teachers set for learners as potential future teachers is very influential indeed. In a small-scale survey of English language teachers (Williams, 2007) in two primary schools in Szeged, I found that teachers claimed to be most influenced by their former teachers. According to Lortie (1975), schoolchildren observe and evaluate their own teachers over thousands of hours and form preconceptions about teaching in an "apprenticeship of observation". These preconceptions about teaching linger on into teacher education and strongly affect practitioners' subsequent teaching - notwithstanding the considerable efforts of teacher education. If this is the case, the cumulative and long-term effect that today's teachers have on future teachers' practice should give rise to teacher training activities in which students confront and compare their preconceptions with the theoretical, practical, and experiential knowledge that is currently available.

In this section, I have described the EAP class which the learners in this study attended, the types of foreign language teaching experience learners are exposed to in primary and secondary schools in this context, and the system of teacher education that largely perpetuates 
the script they develop through that experience. In the following section, I will describe the areas of endeavour that have informed this study.

\section{ReSEARCH PERSPECTIVES}

The present study was informed by three perspectives: the task-based language teaching (TBLT) paradigm; classroom-based research; and learner beliefs research. I will review each of these in turn.

\subsection{The TBLT paradigm}

Central to the TBLT paradigm is the second-language pedagogic task itself. This is defined variously by Breen (1989), Bygate, Skehan, and Swain (2001), Candlin (1987), Ellis (2003), Lee (2000), Long (1985), Nunan (1989), Prabhu (1987), and Skehan (1998). Samuda and Bygate (2008:69) have taken a critical look at Ellis's comprehensive criteria for a task and produced a working definition: "A task is a holistic activity which engages language use in order to achieve some non-linguistic outcome while meeting a linguistic challenge, with the overall aim of promoting language learning, through process or product or both."

With this definition of the task in mind, Samuda and Bygate (2008:196) go on to identify the central characteristics of TBLT in this way:

- "Tasks define and drive the syllabus;

- Task performance is a catalyst for focusing attention on form, and not vice versa;

- Assessment is in terms of task performance;

- Task selection is shaped by real-world activities of relevance to learners and their target needs;

- Tasks play an essential role in engaging key processes of language acquisition."

\subsection{Classroom-based research}

Unlike much research on tasks that takes place under controlled laboratory conditions, classroom-based research attempts to explore the possibilities of tasks in action in authentic classroom conditions. TBLT 2005, the first of a series of biennial international conferences devoted solely to TBLT, pointed out the importance -and dearth- of such research. Examples of such studies include Foster's (1998) exploration of negotiation for meaning in the classroom, and Kumaravadivelu's study (2007), focusing on learners' perceptions of tasks.

Limited resources represent an important aspect of classroom conditions. For instance, time is crucial for adult learners who need to develop the language skills they require particularly for their working lives. Materials and equipment form another concern. González-Lloret (2007) describes how she created CALL materials for her own Spanish language learners at the University of Hawai'i in her own free time and with no funding. Outside the relatively well-equipped and well-funded educational settings of rich countries, the classroom conditions in countries in the periphery (Phillipson, 1992) and semiperiphery (Blagojević, 2004) are arguably much further removed from the laboratory conditions of the SLA classroom 
research studies mentioned above. The need for more research that explores how tasks are actually implemented in intact classrooms is huge.

\subsection{Learner beliefs about language learning}

Learners' beliefs about language learning are commonly thought to impact on their actual language learning processes. In a review of studies on learner beliefs, Bernat and Gvozdenko (2005) concluded that learners' notions about language learning may well affect their motivation, experiences and behaviours in the classroom. As such, these notions could create an obstacle to or a springboard for language learning.

Two early studies explored the character of such beliefs. Wenden (1986; 1987, cited in Ellis, 1994) studied 25 adults learning advanced English at a US university. She elicited their opinions on language learning in semi-structured interviews, using twelve explicit statements, which were divided into three broad categories: (1) how we use the language as we learn it; (2) how we learn about the target language; and (3) what personal factors are involved in language learning. Wenden found that these learners' beliefs represented a wide range of cognitions, but that each learner's set of ideas could easily be placed in one of the three categories she had created.

Horwitz (1987, cited in Ellis, 1994:478) used a 34-item questionnaire (The Beliefs about Language Learning Inventory, or BALLI) to ascertain the beliefs of 32 intermediate learners from a variety of ethnic backgrounds in an Intensive English Programme (IEP) at a US university. Horwitz discusses his findings in terms of five general areas: foreign language learning aptitude; language learning difficulty; the nature of language learning; learning and communication strategies; and motivation and expectations. Ellis (ibid.) highlights the most relevant findings. For example, 81 per cent of the learners held the view that a person either possessed an inborn language learning aptitude or did not - but they also felt certain that they were among the ones who did. Many respondents entertained restrictive ideas about how people learn language: for example, language is best learnt by memorizing vocabulary and grammar rules. And 94 per cent of these learners felt one needed to know about Anglophone cultures to be able to speak English well.

In a small-scale study of two learners, Abraham and Vann (1987, cited in Ellis, 1994) found some proof that beliefs influence learning outcomes. The learners, Gerardo and Pedro, shared some of the same notions about language learning (e.g. it was important to practice as much as possible), but they diverged in other ways (e.g. Gerardo felt attending to grammar was key, while Pedro disliked metalanguage). In the end, Gerardo outperformed Pedro on the TOEFL, whereas Pedro outscored Gerardo on a speaking test. The suggestion was that certain views of language learning may lead to certain kinds of achievement.

But what determines language learning beliefs? In random samples of students of foreign languages at Trinity College, Dublin, Little, Singleton, and Silvius (1984, reported in Little and Singleton (1990:14)) found that "past experience, both of education in general and of language learning in particular, played a major role in shaping attitudes to language learning" (cited in Ellis (1994:479)).

It is this past experience of language learning that I will explore in this study through semi-structured interviews. The purpose of the study is to gain an insight into these learners' scripts and their beliefs about learning and to ascertain how these impact their likelihood to benefit from TBLT, a methodology that is presumed to be novel for them. 


\section{The STUdY}

The current study is part of a larger study that sought to investigate the implementation of TBLT in a Hungarian EFL context. The larger study consists of two phases: the classroom phase and the interviews. The participants fall within a proficiency range of upperintermediate to advanced learners of English. They are 18 to 23 years old and in their first year studying English Language and Literature at the University of Szeged. They attended one of three speaking classes that I was teaching in autumn 2009. The classes were designed to prepare them for an advanced speaking exam at the end of their first year. 56 participants participated in the classroom phase, and 28 took part in the interview portion of the study. I will describe these two phases in detail below.

\subsection{The classroom phase}

The classroom phase consisted of two lessons in two consecutive classes. They each centred on a speaking task that required complex decision-making toward a convergent outcome. These were widely available tasks taken from Penny Ur's fittingly named Discussions that work (1981) (see Appendix). The tasks were read through and explained carefully. They were then performed in dyads and recorded on the learners' own mobile phones. The audio files were later sent to me in an email attachment. As the task was being completed, I observed the dyads and made on their performance for later feedback. I then discussed their performance in terms of content and form. A total of 56 learners participated in these speaking tasks in three separate modules. The transcripts will form the data for another study on the various manifestations of both negotiation for meaning and the more collaborative processes that Samuda and Bygate term "constructivist" (2008:117ff.) which may occur during task performance.

\subsection{The interviews}

I based the design of the interview questions on concepts that are of central concern to TBLT methodology. Questions 1-3 deal with learners' views of form-focused teaching: how form is taught (cf. distinction between Focus on Form v. Focus on Form $S$ in Doughty and Williams, 1998) and how errors are viewed and handled (see e.g. Lyster, 2001). Question 4 addresses group and pair work and thus hints at the reduced role of the teacher (see e.g. Willis, 1996). Question 5 focuses on teachers' promoting learner responsibility - and empowerment (Long, 2005). Questions 6 and 7 examine learners' experience of needs analysis and individualized instruction (ibid.). Question 8 offers the learners an opportunity to provide any additional impressions. Finally, Question 9 has learners look at their -usually first - recent experience of TBLT in our class. The interview questions had two aims: to ascertain the learners' second language learning experience (questions 1-8) and to gather their reflections on their exposure to the TBLT paradigm (question 9).

Each interview lasted between 25 and 35 minutes and was administered one-on-one in my office within two weeks of the task-based lessons. They were recorded on a cassette tape player and subsequently transcribed. A total of 28 volunteers selected at random took 
part from the larger population that had participated in the TBLT classes. The language of the interview was English. The questions were as follows:

1) How important has grammatical correctness been to your foreign language teachers in either the speaking or writing of their students? What do you think about that?

2) How much have your foreign language teachers corrected their students' grammatical errors in the classroom? What kinds of errors have they corrected? What do you think about that?

3) How have you learnt grammar? Many teachers go over a major grammar point, say, the present perfect, have the students practice it, and then move on, assuming it has then been learnt and will not be forgotten. Have you experienced this sort of thing? How do you feel grammar should be covered?

4) How much have your teachers used group or pair work in the foreign language classroom? How useful do you feel that has been? How much do you think it should be used in the classroom?

5. "Learners should take responsibility for their own learning both inside and outside the classroom." Have your teachers tried to encourage this? What do you think of this statement?

6. Have your teachers generally used a given textbook and not other materials or rather a mix of materials? What about their own materials? What is your view of this?

7. Have your teachers used materials or topics that you feel are really interesting? Have they taught you vocabulary and grammar that you feel you will need?

8. What have been the most successful teaching techniques or ideas you have experienced in the past?

9. What did you think of the classes we did with the speaking tasks? What purpose, if any, do you think they served? Do you think a language class made up entirely of such tasks would be effective?

Although these constituted the core questions, I asked additional questions ad hoc as a learner's response seemed to call for further exploration. The results from the learner interviews constitute the data for the present study.

\section{Findings}

Learner responses to the interview questions fell into a number of categories. The most salient points could be divided into three groups: Learning form; Classroom management; and Reflections on the TBLT experience. What follows is a report on the interview findings within those three areas.

\subsection{Learning form}

The learners generally described a learning experience in which grammatical forms and correctness were in the forefront. Some thought that this represented an important foundation 
to language learning, while others found it dry and unmotivating. One learner, János, went so far as to say it had done him no good at all. When asked if he felt that he had been well prepared by classroom instruction in Hungary for spending a year in Australia with his family, he answered, "No, I wasn't. I couldn't speak a word, literally, so I couldn't understand what they were saying and [it] just was confusing." Perhaps it was a matter of an insufficient number of classroom hours before his Australian sojourn. How much classroom instruction had he had? His response was clear. "A lot! I started in Year 3 and finished in Year 11 here and literally couldn't communicate at all, so it was really hard."

Most of the learners reported that teachers used a Focus on Form $S$ approach that was supposed to lead to an incremental mastery of successive forms. Albert explained, "When we learnt a new tense, we came to know everything about it. So I think it's okay because for me I like to learn everything about that tense and I like to know how to use it properly." This comment speaks volumes. Learners schooled in the classical humanist tradition, in which great stock is placed in a demonstrated knowledge of explicit facts, tend to value such an exercise highly.

Closely tied to this notion of mastery is a near intolerance of errors on the part of many teachers. Alexandra speculated about learner anxiety in the following terms: "When we start to learn a language, we have to learn a lot of rules and we have tests and when we make a mistake, just a little mistake, they [teachers] don't want to help us in this way, so they don't correct it but give a mark 1 if you don't know something. It's so frustrating when somebody tells you this is not good and this is not good and this is not good.... It makes us nervous and anxious not to make a mistake...."

The learners also reported certain other approaches to grammar teaching in which form takes precedence over meaning. For instance, Kinga described a German class in which short dialogues were memorized and recited in class as an aid to learning and improving grammar. "It was just to learn how German grammar works, so it was like 'Anna ist eine [sic!] ungarisches Mädchen'. It was the first sentence we had to learn and everyone knew it because we had to memorize it and it was good because we remembered ... that sentence. If you forget [how to say] 'Hungarian' [you realise] oh, it's 'ungarisches' and we knew that from the sentence, so it was good in that way." Clearly, Kinga felt this technique had been successful. Likewise, Csaba described class work with fill-in-the-gap practice grammar tests as an effective way to improve grammar. Indeed, the view that succeeding on a written grammar test —often a context-free, discrete-item multiple-choice test - signifies language learning success is commonly held by the respondents. Translation exercises were also considered to be an effective way of improving language proficiency.

In contrast, Dávid spoke of immersion French lessons in which forms were covered as problems arose in communication, usually through speaking. He described a very motivating and creative classroom atmosphere. His account differed from most of the others'.

\subsection{Classroom management}

Learners by and large described a teacher-fronted style of classroom management. The teacher typically interacts with the students by asking them questions, which are primarily of the display type, in which a simple demonstration of previously taught knowledge is required. Conversely, after a detailed explanation, a teacher might ask, "Is that clear?", typically eliciting a face-saving silence. 
As for the methodological formats their teachers used, the respondents mentioned the following:

- "We rather worked individually. We got a task, we had to do it, and we spoke about it, [but] I don't remember that we did anything like this [pair work or group work]."

- "We did group work ... more or less when we prepared for a final exam or a language exam, for example we were working in groups for [speaking exam] practice, but sometimes we didn't work in groups because it wasn't needed."

- "I can't think of any good activities that we did. Maybe in the first five minutes of the class, where we would have a bit of a chat with the teacher."

- "The teacher talks and the student listens and you do work at home."

In contrast, several learners had been familiarized with independent class work. For instance, Anett described her experience with one secondary school EFL teacher: "We were given a topic and then we had to give our opinion, but in bigger groups - I don't know why, but it was always in bigger groups of four or five. We talked about a topic like women in society, gave our opinions, and told them to the class.... And that was motivating, I think, because everyone has a strong opinion on those kinds of topics."

\subsection{Reflections on the speaking tasks}

Both in class and in the interviews, the learners by and large responded favourably to the two sessions they had participated in. They were stimulated by a good argument, by the need to convince others of their view, by what they perceived to be the quirky, but ultimately realistic quality of the tasks, and by the challenge of being forced to arrive at a difficult decision.

For example, Dóra's comment was typical of the positive reactions, though her impressions might also have been coloured by previous classroom experiences: "Well, it was good for speaking because we could argue ... and we had many options ... but I [have always had] a strange feeling about working in groups because my experience, especially in the grammar school, was that everyone started to speak in Hungarian: 'OK, what did you see on TV last week?' We didn't do the task properly." Naturally, such a failure in group or pair work could have been due to the task design or task implementation or both - or, indeed, the activities in question might not even have met the criteria for a task at all.

None of the learners raised the common objection of two native speakers of one language perhaps finding it absurd to communicate in a language which is foreign to both of them. This may owe much to the design of the tasks. One naturally loses oneself in the work of completing them and forgets one's inhibitions. However, several learners expressed the concern of two Hungarians not necessarily noticing each other's errors and certainly not correcting them if they were noticed. For such learners, feedback must be immediate.

A complaint that several learners voiced was that their partner was unwilling to talk and that the conversation was therefore one-sided. Such reticence is not uncommon among Hungarians, and it surely cannot be helped - and may even be promoted - by the common teacher concern about errors noted above. 


\section{Discussion}

The results of this qualitative study appear to present a somewhat grimmer picture of foreign language teaching in Hungary than the findings of Nikolov and her colleagues. These learners seemed to have experienced less meaning-focused, learning-centred, holistic, real-world pedagogy than even those researchers identified in their studies. This could be because successful foreign language learners such as the ones in this study who have personal knowledge of several kinds of teaching techniques with several different teachers are willing or able to speak more critically about their language learning.

Overall, the learners seemed positively disposed towards TBLT, despite foreign language learning histories often marked by the kinds of teacher-fronted, grammar- and translationoriented classroom environments Nikolov and her colleagues described. Although some of the learners expressed a preference for such practices as translation, form-dominated exercises, and text memorization, they also saw the pedagogic benefits of a task-based paradigm.

A learner's script is closely linked to a learner's beliefs. After all, if a learner expects certain things to happen in the foreign language classroom, she or he presumably also believes that they will work. At this point, let us recall Bernat and Gvozdenko's (2005) observation (from the earlier section on learner beliefs research) that learners' views about language learning may well affect their motivation, and their experiences and behaviours in the classroom and that these views could thus hinder or boost their language learning success. If the learners in this study generally both understand and accept TBLT, then this would presumably suggest potential success with this paradigm.

\section{IMPLICATIONS}

The findings of the study may have implications for top-down or bottom-up innovation in language teaching as well as for pre-service and in-service teacher education. If effective, principled teaching practices are to be adopted in the classroom, it starts with making clear to both perspective and current teachers what their own beliefs are about learning and teaching - beliefs that were set long before they entered their first methodology class - and to encourage them to elaborate a principled set of teaching techniques to replace the intuitive sense of what teaching techniques work that so many teachers developed long ago largely based on their own "apprenticeship of observation."

The findings also suggest that learners' script and language beliefs may not necessarily be carved in stone. A learner may well be open even to a teaching paradigm that she or he has only recently been exposed to if it appears to work and if the rationale behind it is made clear.

Finally, as described in the section on classroom-based research, such studies take a close look at tasks in action under the ordinary classroom conditions that would exist without a researcher involved. They come with an understanding of limited resources, materials, and equipment, as applies in the context of the semiperiphery noted in this study, where a resourceful and flexible approach remains essential to success in the classroom. It is hoped that the findings in this study will be of particular interest to teachers and educational 
managers in similar circumstances and that the research procedures described in this study will be reproduced or that similarly straightforward procedures will be developed for further much-needed classroom-based research.

\section{Conclusion}

According to Hungary's Census of 2001, the percentage of Hungarians who said they knew at least one foreign language - i.e. any foreign language even at a basic level - stood at 19.2 per cent (Hungarian Central Statistical Office, 2003). The census also found that English proficiency among 15- to 39 -year-olds came to $18.4 \%$, whereas among perspective college/university graduates with at least one year of higher education - the population that would presumably show the most promising numbers - the figure was a mere 52 per cent (ibid.). In addition, it showed that English proficiency in Hungary in general stands at $9.2 \%$, well below the EU average then of $41 \%$ and even below the percentages for Italy and Portugal of $39 \%$ and $36 \%$, respectively (ibid.).

Over twenty years after Hungary's regime change putatively paved the way for new options in FL teaching, the conventional wisdom among stakeholders as to why our language learning environment is as it is still includes:

- the relative difficulty for speakers of Hungarian in learning English, and, indeed, any Indo-European language, due to their linguistic distance from Hungarian;

- a history of Russian language teaching perceived as ineffectual and the impact this has had on many adults today - teachers, learners, and parents of young learners;

- the preponderance of dubbing over sub-titles in television programmes and films with its implications for regular exposure to foreign languages; and

- the persistence of the Grammar-Translation Method with attendant concerns vis-à-vis learner motivation and communicative effectiveness.

- Reasons abound, therefore, indicating that, the dismal numbers notwithstanding, a perception clearly exists among stakeholders that there is indeed a problem.

Certainly, Hungary's language learning situation is not unique. Neighbouring countries in Central Eastern Europe show comparable numbers and share many of the same teacherfronted, grammar-translation-oriented, classical humanist educational tendencies. Moreover, globally, Stern (1983) and others are cited in Skehan (1996) as remarking that learners exposed to conventional foreign language learning tend to reach very low levels of proficiency and come away from school with little usable language. This even prompted Skehan (ibid.) to conclude that "most language learning is associated with relative failure."

The solution for L2 teaching in Hungary, and perhaps for many other similar EFL contexts, may well lie in the theory and practice of TBLT. Certainly, the participants in this study - having attained sufficiently high scores on a language exam to be admitted into the English Studies programme at university and indeed having shown strong communicative skills both in class and in the interviews - can reasonably be described as successful language learners, in spite of possible shortcomings in the classroom teaching they experienced. 
Still, if the dismal numbers are to be believed, these learners constitute the exception. How many language learners in this country (and elsewhere) fall by the wayside? And how many succeed in form-oriented language exams only to realise that their language skills have little application to their real-world needs?

One wonders if the learners' script that suggests a certain reliance on tools like translation and an incremental approach to teaching form should lead one to conclude that a tasksupported programme (Samuda and Bygate, 2008) should be implemented to ease learners and teachers into a sort of merger between the more familiar and the more effective or if a bolder application of core task-based language teaching (as in Flanders, see Van den Branden, 2006) is in order to afford learners and teachers an opportunity to develop a new script.

\section{ReFERENCES}

Abraham, R. and R. Vann. (1987). "Strategies of two language learners: A case study", in A. Wenden and J. Rubin (eds.), Learner Strategies in Language Learning. Cambridge: Prentice Hall, 85-102.

Bernat, E. and I. Gvozdenko. (2005). "Beliefs about language learning: Current knowledge, pedagogical implications, and new research directions", in TESL-EJ, 9, 1: 1-21.

Blagojević, M. (2004). "Creators, transmitters, and users: Women's scientific excellence at the semiperiphery of Europe", in European Education, 36, 4: 70-90.

Bors, L., R. Lugossy, and M. Nikolov. (2001). "Az angol nyelv oktatásának átfogó értékelése pécsi általános iskolákban [A comprehensive assessment of EFL instruction in the primary schools of Pécs]", in Iskolakultúra, 11, 4: 73-88.

Breen, M. (1989). "The evaluation cycle for language learning tasks", in R.K. Johnson (ed.), The Second Language Curriculum. Cambridge: Cambridge University Press, 187-206.

Bygate, M., P. Skehan, and M. Swain. (eds.). (2001). Researching Pedagogic Tasks: Second Language Learning, Teaching, and Testing. Harlow: Longman.

Candlin, C. (1987). "Towards task-based language learning”, in C. Candlin and D. Murphy (eds.). Language Learning Tasks. Englewood Cliffs, N.J.: Prentice Hall International, 5-21.

Doughty, C. and J. Williams. (eds.). (1998). Focus on Form in Classroom Language Acquisition. Cambridge: Cambridge University Press.

Ellis, R. (1994). The Study of Second Language Acquisition. Oxford: Oxford University Press.

Ellis, R. (2003). Task-based Language Learning and Teaching. Oxford: Oxford University Press.

Foster, P. (1998). "A classroom perspective on the negotiation of meaning", in Applied Linguistics, 19, 1: 1-23.

González-Lloret, M. (2007). "Implementing task-based language teaching on the web". In K. Van den Branden, K. Van Gorp, and M. Verhelst (eds.). Tasks in Action: Task-based Language Education from a Classroom-based Perspective. Newcastle: Cambridge Scholars Publishing, 265-284.

Horwitz, E. (1987). "Surveying student beliefs about language learning", in A. Wenden and J. Rubin (eds.). Learner Strategies in Language Learning. Cambridge: Prentice Hall, 119-129.

Hungarian Central Statistical Office. (2003). "A nyelvtudás Magyarországon [Foreign language proficiency in Hungary]”, in EU-Számunió. 14 March 2003, No. 5. Available at http:// portal.ksh.hu/pls/portal/url/ITEM/E6262A4E30E56EA8E03400306E4816D2, accessed 5 June 2005. 
Kumaravadivelu, B. (2007). "Learner perception of learning tasks", in K. Van den Branden, K. Van Gorp, and M. Verhelst (eds.), Tasks in action: Task-based Language Education from a Classroom-based Perspective. Newcastle: Cambridge Scholars Publishing, 7-31.

Lee, J. (2000). Tasks and Communicating in Language Classrooms. Boston: McGraw-Hill.

Little, D. and D. Singleton. (1990). "Cognitive style and learning approach", in R. Duda and P. Riley (eds.), Learning Styles. Nancy, France: University of Nancy, 11-19.

Long, M. (1985). "A role for instruction in second language acquisition: Task-based language teaching", in K. Hyltenstam and M. Pienemann (eds.), Modelling and Assessing Second Language Acquisition. Clevedon: Multilingual Matters, 77-99.

Long, M. (2005). TBLT: Building the road as we travel. Plenary address, $1^{\text {st }}$ International Conference on Task-based Language Teaching. University of Leuven.

Lortie, D. (1975). Schoolteacher: A Sociological Study. Chicago: University of Chicago Press.

Lyster, R. (2001). "Negotiation of form, recasts, and explicit correction in relation to error types and learner repair in immersion classrooms", in R. Ellis (ed.), Form-focused Instruction and Second Language Learning. Malden, Mass.: Blackwell Publishers, 265-301.

Medgyes, P. (1996). "Foundations", in P. Medgyes and A. Malderez. (eds.), Changing Perspectives in Teacher Education. Oxford: Macmillan Heinemann, 1-11.

Medgyes, P. and A. Malderez. (eds.). (1996). Changing Perspectives in Teacher Education. Oxford: Macmillan Heinemann.

Nikolov, M. (1999). "Osztálytermi megfigyelés átlagos és hátrányos helyzetü középiskolai angolos csoportokban [Classroom observation in average and remedial secondary school EFL groups]", in Modern Nyelvoktatás, 5, 4: 9-31.

Nikolov, M. (2000). "Kódváltás pár- és csoportmunkában általános iskolai angolórákon [Codeswitching in pair and group work in primary school EFL classes]", in Magyar Pedagógia, 100, 4: 401-22.

Nikolov, M. (2003). "Angolul és németül tanuló diákok nyelvtanulási attitűdje és motivációja [Language learning attitudes and motivation among EFL and German as a Foreign Language learners]", in Iskolakultúra, 13, 8: 51-73.

Nikolov, M. (2008). “‘Az általános iskola, az módszertan!’: Alsó tagozatos angolórák empirikus vizsgálata ['Primary school means methodology!': An empirical study of lower school EFL classes]", in Modern Nyelvoktatás, 14, 1-2: 3-19.

Nikolov, M. and E. Nagy. (2003). “'Sok éve tanulok, de nem jutottam sehova': Felnőttek nyelvtanulási tapasztalatai ['I've been learning this language for years, but have never got anywhere.': Adult language learning experience]", in Modern Nyelvoktatás, 9, 1: 14-40.

Nunan, D. (1989). Designing Tasks for the Communicative Classroom. Cambridge: Cambridge University Press.

Phillipson, R. (1992). Linguistic Imperialism. Oxford: Oxford University Press.

Pintér, A. (2007). "What children say: Benefits of task repetition", in K. Van den Branden, K. Van Gorp, and M. Verhelst (eds.), Tasks in Action: Task-based Language Education from a Classroom-based Perspective. Newcastle: Cambridge Scholars Publishing, 131-158.

Pohl, U. (1996). "Theorizing for the classroom", in P. Medgyes and A. Malderez. (eds.), Changing Perspectives in Teacher Education. Oxford: Macmillan Heinemann, 47-57.

Prabhu, N.S. (1987). Second Language Pedagogy. Oxford: Oxford University Press.

Rádai, P. and T. Shanklin. (1996). "Language matters", in P. Medgyes and A. Malderez. (eds.), Changing Perspectives in Teacher Education. Oxford: Macmillan Heinemann, 25-35.

Samuda, V. and M. Bygate. (2008). Tasks in Second Language Learning. Basingstoke, UK: Palgrave Macmillan. 
Skehan, P. (1996). "Second language acquisition research and task-based instruction", in J. Willis and D. Willis (eds.), Challenge and Change in Language Teaching. Oxford: Heinemann, 17-30.

Skehan, P. (1998). A Cognitive Approach to Language Learning. Oxford: Oxford University Press.

Stern, H. (1983). Fundamental Concepts in Language Teaching. Oxford: Oxford University Press.

Ur, P. (1981). Discussions That Work. Oxford: Oxford University Press.

Van den Branden, K. (ed.). (2006). Task-based Language Teaching: From Theory to Practice. Cambridge: Cambridge University Press.

Wallace, M. (1991). Training Foreign Language Teachers. Cambridge: Cambridge University Press.

Wenden, A. (1986). "What do second language learners know about their language learning? A second look at retrospective accounts", in Applied Linguistics, 7, 186-201.

Wenden, A. (1987). "How to be a successful learner: Insights and prescriptions from L2 learners", in A. Wenden and J. Rubin (eds.), Learner Strategies in Language Learning. Cambridge: Prentice Hall, 103-116.

White, R. (1988). The ELT Curriculum: Design, Innovation and Management. Oxford: Blackwell.

Williams, T. (2007). Whither Hungarian TEFL?: Changes in the field and their implications for Hungary. Hungarian Society for the Study of English Conference, University of Szeged, Hungary.

Willis, J. (1996). A Framework for Task-based Learning. Harlow: Longman. 


\section{Appendix}

The two speaking tasks performed in dyads during the classroom phase of the study require complex decision-making toward a convergent outcome.

\section{Task 1: The scholarship}

Goal: To agree on which of the following candidates should win a scholarship to study law at your university. Only one candidate can win it.

Albert Smith Aged 37, not of outstanding natural ability but very hard-working. Married with three children; until now a taxi driver. His applying was probably due largely to his wife's ambition. Albert made a good impression, but seems a little nervous at the whole idea of law school and the effects his new career might have on his social life and family. If he fails the scholarship he will go back to taxi driving.

Basil Katz Aged 19, brilliant but not very hard-working. A likeable personality, of leftwing sympathies, has taken part in some more or less violent demonstrations and has been in prison at least once as a result. Lots of girlfriends, has a reputation for treating them badly. Very musical, has founded and runs a pop group. Will probably make this his career if he fails the scholarship, which would be a 'terrible waste' according to his school tutor who recommends him.

Carole Anderson Aged 20, a quiet, attractive girl, responsible and able, but rather pliable in character, engaged to be married to a doctor, would like to finish her university studies before settling down. Her fiancé says: 'I want Carole to fulfil herself in every way, but of course once she is married, home and children will occupy her first and foremost.' Her parents cannot afford to finance the course.

Daphne Braun Aged 21, single, the daughter and granddaughter of lawyers. Enthusiastically Women's Lib., ambitious and career-minded. Academic record erratic, some very good results, some mediocre. Had a mental breakdown last year, was in hospital for three months but appears to have made a complete recovery. Fined recently for being in possession of marijuana. Parents cannot finance her studies. In character rather aggressive and quick-tempered, but generous, a good friend.

Edward Mbaka Aged 24, has been in the Army and seen active service. Divorced, no family. Highly motivated, wants eventually to go into politics. 'I want this course more than anything,' he says, 'and only the scholarship can get it for me.' While in the army he was once found guilty of accepting bribes. Charming personality, fluent and eloquent speaker. A citizen of this country, but retains the nationality of his native African state, to which he may eventually return. 


\section{Task 2: Lord Moulton's millions}

Goal: To agree on which of the following potential heirs should inherit all of the late Lord Moulton's millions. There can only be one heir, and Lord Moulton has not left a will.

Lady Searle Lord Moulton's widowed cousin, his only living relative, aged 66, living alone in a small village in comfortable but not luxurious circumstances. The money would enable her to hire a nurse (she is often ill), travel, move into pleasanter surroundings. She has no immediate family, is not very popular in her neighbourhood. Has not been on speaking terms with Lord Moulton for years, following a quarrel.

Miss Langland The nurse who attended Lord Moulton for the last four years of his life, 48 years old, loves her work and is professionally very able. Was very well paid by Lord Moulton, and her savings will enable her to take a long holiday before taking up another similar post. An affectionate and loyal attendant, she undoubtedly eased Lord Moulton's latter years.

Tim Brodie The son of Lord Moulton's gardener. Lord Moulton took a liking to him, paid for his education and took a constant interest in his welfare. Tim, who has a flair for languages, desperately wants to study abroad, but has no money so will have to get a job and save if he can. An attractive and popular young man, drives a motorbike much too fast, lots of girlfriends, not very honest.

Jane Smith A penniless young unmarried woman with a small baby who has recently appeared on the scene claiming to be Lord Moulton's daughter. Has a letter which appears to be in Lord Moulton's writing and signed by him, addressed to her mother (now dead) admitting paternity and proposing marriage. Refuses to give any further details of her past life, and has no references.

The local orphanage A charity which receives no help from the State, though new legislation might change this. It has occasionally received donations from Lord Moulton in the past and is certainly badly in need of funds. However, it is badly run, and there is a possibility that much of the money might find its way into the pockets of officials rather than being used for the orphans.

- Speaking tasks taken from Ur, P. (1981). Discussions That Work. Oxford: Oxford University Press. 